\title{
PEMBELAJARAN MATEMATIKA MENGGUNAKAN CD INTERAKTIF AMT BERBASIS LECTORA INSPIRE UNTUK SISWA SD
}

\author{
Sukamto' \& Asry Kusuma Wardani² \\ 1,2PGSD Universitas PGRI Semarang \\ 1,2 Jl. Sidodadi Timur No. 24 Semarang \\ 'Email: chamtorafa@yahoo.com \\ 2Email: asrykusumawardani@yahoo.com
}

\begin{tabular}{l} 
ABSTRACT \\
\hline The purpose of this research is consider the \\
effectivness of mathematic learning using lectora \\
inspire based interactive CD in primary school. \\
This research is a research and development with \\
design ADDIE. The validity of he return products \\
developed by votes validator media experts and \\
material to obtain a valid criterion. Products in \\
the validation by experts and the media matter \\
experts, and then tested. Sample test was grade \\
4 students of elementary school Tandang 01 \\
Semarang. Results of the media validation \\
analysis experts the average percentage of \\
media ideals, respectively for $68.00 \%$ and $89.58 \%$. \\
Results of the validation analysis matter experts \\
the average percentage of media ideals, \\
respectively for $74.67 \%$ and $90.42 \%$ and the \\
response to all students in grade IV B of \\
elementary school of Tandang 01 Semarang by \\
$87.64 \%$. Based on the test results are known to $\dagger$ \\
over ttable (9.056> 2.030). Differences in student \\
learning outcomes before and after being \\
treated was 59\%. From the analysis, AMT \\
interactive CD categorized as very good. So it \\
can be applied in teaching.
\end{tabular}

Keywords: interactive CD, lectora inspire, learning outcomes.

\begin{abstract}
ABSTRAK
Tujuan penelitian ini adalah untuk mengetahui keefektifan pembelajaran matematika dengan menggunakan CD interaktif berbasis lectora inspire pada siswa SD. Penelitian ini merupakan penelitian pengembangan dengan menggunakan desain ADDIE. Kevalidan produk yang dikembangkan berdasarkan penilaian validator pakar/ahli media dan materi untuk mendapatkan kriteria valid. Produk yang dikembangkan setelah dinyatakan valid oleh pakar/ahli, diujicobakan di lapangan. Sampel ujicoba adalah siswa kelas IV SD Tandang 01 Semarang. Hasil validasi produk dinyatakan valid, berdasarkan hasil validasi pakar/ahli media rata-rata persentase keidealan media berturutturut sebesar $68,00 \%$ dan $89,58 \%$. Hasil analisis data validasi ahli materi rata-rata persentase keidealan media berturut-turut sebesar $74,67 \%$ dan $90,42 \%$, dan respon siswa sebesar $87,64 \%$. Berdasarkan hasil uji- $\dagger$ diketahui to lebih dari tabel $(9,056>2,030)$. Perbedaan hasil belajar siswa sebelum dan sesudah diberi perlakuan adalah 59\%. Dari hasil analisis tersebut, dapat disimpulkan bahwa CD interaktif AMT dikategorikan efektif, sehingga dapat diterapkan dalam pembelajaran.
\end{abstract}

Kata kunci: CD interaktif, lectora inspire, hasil belajar.

How to Cite: Sukamto, S., \& Wardani, A. (2016). PEMBELAJARAN MATEMATIKA MENGGUNAKAN CD INTERAKTIF AMT BERBASIS LECTORA INSPIRE UNTUK SISWA SD. Mimbar Sekolah Dasar, 3(1), $19-28$. doi:http://dx.doi.org/10.17509/mimbar-sd.v3i1.2353.

\begin{abstract}
PENDAHULUAN Pendidikan merupakan sesuatu yang sangat penting bagi manusia dalam menjalani kehidupan di dunia ini. Dengan pendidikan orang dapat mengetahui apa yang belum diketahui. Dengan pendidikan pula orang dapat mencapai apa yang diinginkan.
\end{abstract}

Tanpa adanya pendidikan orang akan bodoh selamanya. Untuk itu pemerintah memiliki cita-cita yang tercantum dalam pembukaan UUD 1945 yang berbunyi "mencerdaskan kehidupan bangsa". Citacita luhur itu diupayakan dengan didirikannya sekolah-sekolah di mana di 
Sukamto \& Asry Kusuma Wardani, Pembelajaran Matematika Menggunakan CD Interaktif...

dalam sekolah tersebut dilaksanakan sebuah pendidikan.

Berdasarkan Undang-Undang Republik Indonesia Nomor 20 Tahun 2003, Pasal 1 ayat 19, tentag Sistem Pendidikan Nasional (Sisdiknas). Pendidikan adalah usaha sadar dan terencana untuk mewujudkan suasana belajar dan proses pembelajaran agar peserta didik secara aktif mengembangkan potensi dirinya untuk memiliki kekuatan spiritual, keagamaan, pengendalian diri, kepribadian, kecerdasan, akhlak mulia, serta keterampilan yang diperlukan dirinya, masyarakat, bangsa dan negara.

Pendidikan dilaksanakan di semua tempat di mana saja dan kapan saja. Pelaksanaannya dari waktu ke waktu selalu berubah sesuai dengan perkembangan zaman. Untuk itu pendidikan harus disesuaikan dengan jaman dan kebutuhan. Karena itu perbaikan kualitas dari segala unsur yang mempengaruhi pendidikan, yang terdiri atas murid, guru, petugas perpustakaan, kepala sekolah, bahan atau materi pelajaran (buku, modul selebaran, majalah, rekaman video atau audio, dan yang sejenisnya), serta berbagai sumber belajar dan fasilitas (overhead projector, perekam pita audio dan video, radio, televisi, komputer, perpustakaan, laboratorium, pusat sumber belajar, dan lain-lain).
Tuntutan profesionalitas guru memberi dampak yang besar pada perubahan bidang pendidikan. Guru sebagai pengelola pembelajaran dituntut untuk lebih kreatif dan inovatif agar membuat hasil pembelajaran lebih optimal. Variasi dalam pembelajaran sangatlah dibutuhkan oleh seorang guru, karena pembelajaran konvensional cenderung kurang menarik minat belajar siswa. Minat siswa yang kurang ini juga dapat dipengaruhi karena ada beberapa mata pelajaran yang sering dianggap sulit oleh siswa.

Berdasarkan hasil wawancara di beberapa sekolah di kota Semarang, matematika memiliki peringkat pertama mata pelajaran yang dianggap sulit bagi siswa. Padahal matematika merupakan salah satu materi yang diujikan dalam ujian nasional pada setiap jenjang pendidikan mulai dari SD sampai SMA. Materi yang diajarkan juga saling berkaitan dan selalu dikembangkan lebih luas di setiap jenjang pendidikan. Dengan demikian, dibutuhkan penanaman konsep yang matang pada siswa. Namun kurangnya minat belajar siswa pada mata pelajaran ini membuat mereka juga sulit memahami materi konsep-konsep dalam matematika. Di sekolah dasar ada beberapa materi yang memiliki tingkat kesulitan yang tinggi (Karim, 1996). Operasi hitung bilangan bulat merupakan salah satu materi yang diujikan dalam ujian nasioal, dan selalu menjadi soal yang memiliki tingkat kesulitan yang tinggi. 
Kurangnya penanaman konsep melalui media pembelajaran yang inovatif yang digunakan, membuat siswa makin sulit untuk memahami konsep operasi hitung bilangan bulat.

Setiap sekolah pastilah memiliki berbagai sumber belajar dan fasilitas yang berbeda. Beberapa sekolah bahkan sudah memiliki fasilitas yang cukup lengkap. Fasilitas elektronik seperti perangkat komputer, laptop, internet, overhead projector, dan fasilitas lainnya yang sudah ada di beberapa sekolah. Namun kadang justru terbengkelai dan kurang dimanfaatkan oleh guru sebagai penunjang dalam pembelajaran. Hal ini disebabkan karena kurangnya kreativitas guru dalam mengoptimalkan kemampuannya di bidang teknologi dan informasi.

Pada masa saat ini, guru dituntut untuk mengikuti perkembangan teknologi yang ada agar pembelajaran yang diberikan pada siswa sesuai dengan perkembangan yang ada di lingkungannya. Perubahan dalam sebuah perkembangan zaman tidak dapat ditolak maupun dihindari, oleh karena perlu adanya antisipasi terhadap perubahan tersebut. Misal, pengembangan suatu media penunjang yang cocok dengan karakteristik siswa sekolah dasar sekaligus wujud hasil antisipasi terhadap perubahan lingkungan yang terus terjadi.

Gerlach \& Ely (dalam Arsyad, 2013, p. 3) mengatakan bahwa media apabila dipahami secara garis besar adalah manusia, materi, atau kejadian yang membangun kondisi yang membuat siswa mampu memperoleh pengetahuan, keterampilan, atau sikap. Dalam pengertian ini, guru, buku teks, dan lingkungan sekolah merupakan media. Media pembelajaran sangat membantu baik siswa maupun guru dalam proses pembelajaran di kelas. Pemanfaatan media pembelajaran yang sesuai dapat menumbuhkan minat belajar, bahkan meningkatkan hasil belajar siswa (Daryanto, 2013).

Perkembangan teknologi informasi dan komunikasi pada saat ini telah membawa perubahan yang besar dalam berbagai aspek kehidupan manusia, perkembangan tersebut juga telah mengubah pandangan manusia dalam mencari dan mendapatkan informasi semakin mudah. Hal ini menuntut seorang guru untuk berpikir lebih maju dengan inovasi yang lebih baik dibandingkan sebelumnya. Salah satu wujud pemikiran baru tersebut adalah media pembelajaran yang efektif. Sebagai contoh, media pembelajaran yang bersumber dari teknologi komputer yaitu berupa CD interaktif dengan Lectora Inspire.

Berdasarkan permasalahan dan potensi di atas, perlu kiranya dilakukan pengembangan $C D$ interaktif AkU MaU Tahu (AMT) dengan Lectora Inspire materi operasi hitung bilangan bulat untuk kelas 
Sukamto \& Asry Kusuma Wardani, Pembelajaran Matematika Menggunakan CD Interaktif...

IV. Media ini bertujuan membantu siswa dalam belajar operasi hitung bilangan bulat yang merupakan materi dalam mata pelajaran matematika yang memiliki tingkat kesulitan yang tinggi, sehingga mampu menarik perhatian siswa dengan belajar lebih aktif melalui pembelajaran elektronik secara mandiri dengan penuh antusias.

\section{METODE}

Jenis penelitian yang digunakan peneliti adalah penelitian dan pengembangan (Research and Development). Metode penelitian dan pengembangan atau dalam bahasa Inggrisnya Research and Development adalah metode penelitian yang digunakan untuk menghasilkan produk tertentu, dan menguji keefektifan produk tersebut (Soegeng, 2006; Sugiyono, 2010; Setyosari, 2012; Sukmadinata, 2013).

Penelitian dan pengembangan ini akan menghasilkan CD Interaktif AMT dengan Lectora Inspire yang memuat materi operasi hitung bilangan bulat kelas IV SD semester II. Prosedur dalam penelitian pengembangan ini menerapkan prosedur ADDIE. Metode penelitian dan pengembangan adalah metode yang digunakan untuk menghasilkan produk tertentu. Adapun skema prosedur ADDIE (Pribadi, 2009, p. 125) sebagai berikut:

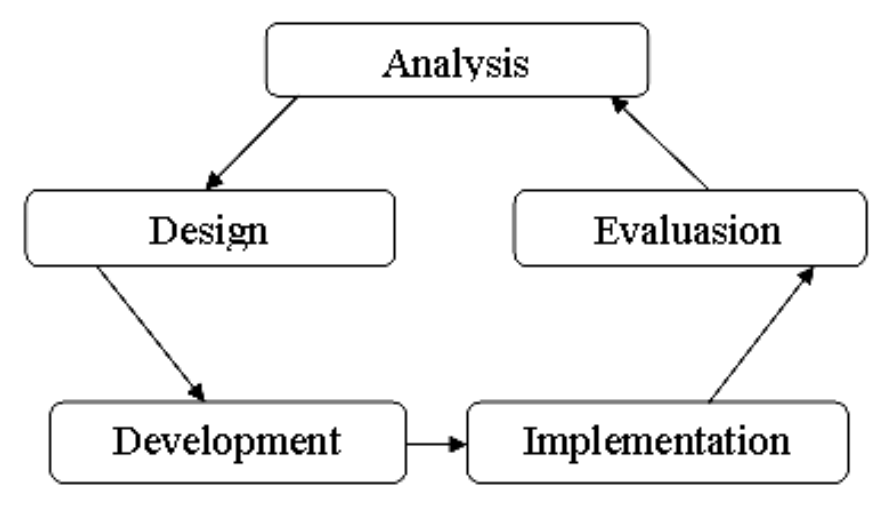

Gambar 1. Tahapan Model ADDIE

\section{Analisis}

Pada fase analisis (analysis), dilakukan pendefinisian permasalahan instruksional, tujuan instruksional, dan sasaran pembelajaran. Pada fase ini juga dilakukan identifikasi atas lingkungan pembelajaran, pengetahuan dan keahlian yang saat ini sudah dimiliki oleh siswa. Fase ini dilakukan untuk menjawab pertanyaan-pertanyaan terkait hal-hal berikut: (1) Siapa penggunanya (audiens)? (2) Apa yang perlu mereka pelajari ? (3) Opsi apa saja yang tersedia untuk menyajikan materi (delivery)? (4) Kendala apa saja yang ada? (5) Kapan proyek harus selesai? dan (6) Apa yang harus dilakukan siswa untuk mengetahui kompetensi mereka? 


\section{Desain}

Fase desain (design) terkait dengan penentuan sasaran, instrumen penilaian, latihan, konten, dan analisis yang terkait materi pembelajaran, rencana pembelajaran dan pemilihan media. Fase desain dilakukan secara sistematis dan spesifik. Aktivitas yang dilakukan pada tahap desain biasanya meliputi pemilihan lingkungan belajar yang paling sesuai dengan mempelajari jenis keahlian kognitif yang diperlukan untuk mencapai tujuan instruksional, menulis sasaran instruksional, memilih pendekatan secara keseluruhan, bentuk dan tampilan program: unit outline, pembelajaran dan modul, merancang materi kursus secara spesifik untuk digunakan pada medium elektronik interaktif.

\section{Pengembangan}

Pada fase pengembangan (development) dilakukan pembuatan dan penggabungan aset konten yang sudah dirancang pada fase desain. Pada fase ini dibuat storyboard, penulisan konten dan perancangan grafis yang diperlukan. Jika melibatkan CD interaktif, programmer akan bekerja untuk mengintegrasikan teknologi yang diperlukan. Aktivitas yang dilakukan pada fase ini meliputi pembuatan atau pengumpulan media yang diperlukan, menggunakan kekuatan internet atau media elektronik untuk menyajikan informasi dalam berbagai format multimedia sehingga dapat memenuhi keinginan siswa, dan mendefinisikan interaksi yang sesuai, yang harus dalam bentuk kreatif, inovatif, dan mendorong siswa untuk terpancing belajar lebih lanjut.

Langkah-langkah dalam menyusun dan mengembangkan CD Interaktif AMT dijelaskan sebagai berikut: (a) menetapkan tujuan pengembangan; (b) mengidentifikasi Standar Kompetensi dan Kompetensi Dasar; (c) menyusun desain CD interaktif AMT; (d) menyusun Rencana Pelaksanaan Pembelajaran (RPP).

\section{Implementasi}

Penerapan CD Interaktif AMT dilaksanakan di kelas IV SD Negeri Tandang 01 dengan tujuan untuk mengenalkan siswa tentang materi menanamkan konsep operasi bilangan bulat. Media yang baik perlu dilakukan validasi terlebih dahulu. Validasi atau uji validitas sangat penting dilakukan untuk menguji produk atau desain yang dikembangkan layak atau tidak jika diterapkan untuk pembelajaran. Uji validitas yang dilakukan meliputi validasi ahli media pembelajaran dan validasi ahli materi pembelajaran. Sugiyono (2010, p. 414) menyatakan validasi desain sebagai berikut:

Validasi desain merupakan proses kegiatan untuk menilai apakah rancangan produk, dalam hal ini metode mengajar bary secara rasional akan lebih efektif dari yang lama atau tidak. Dikatakan secara rasional, karena validasi di sini masih bersifat penilaian berdasarkan pemikiran rasional, belum fakta lapangan. Validasi produk dapat dilakukan dengan cara 
Sukamto \& Asry Kusuma Wardani, Pembelajaran Matematika Menggunakan CD Interaktif...

menghadirkan beberapa pakar atau tenaga ahli yang sudah berpengalaman untuk menilai produk baru yang dirancang tersebut. Setiap pakar diminta untuk menilai desain tersebut, sehingga selanjutnya dapat diketahui kelemahan dan kekuatannya. Validasi desain dapat dilakukan dalam forum diskusi. Sebelum diskusi peneliti mempresentasikan proses penelitian sampai ditemukan desain tersebut, berikut keunggulannya.

Menurut Sugiyono (2010, p. 414), setelah desain produk, divalidasi melalui diskusi dengan pakar dan para ahli lainnya, maka akan diketahui kelemahannya. Kelemahan tersebut selanjutnya dicoba untuk dikurangi dengan cara memperbaiki desain. Yang bertugas memperbaiki desain adalah peneliti yang mau menghasilkan produk tersebut.

Pada tahapan ini, bertujuan untuk mendapatkan desain CD Interaktif AMT yang valid. Revisi produk dilakukan apabila desain belum mencapai tingakatan valid yang diharapkan. Pihak yang berperan penting pada tahap ini adalah ahli media dan ahli materi pembelajaran yang menentukan apakah desain perlu direvisi atau sudah sesuai. Apabila CD Interaktif AMT yang sudah direvisi atau diperbaiki selanjutnya dapat diterapkan pada kelas ujicoba. Pada tahapan ujicoba, media pembelajaran diimplementasikan oleh peneliti.

\section{Evaluasi}

Fase evaluasi terdiri atas dua bagian yaitu formatif dan sumatif. Evaluasi formatif terjadi di setiap tahapan proses ADDIE. Evaluasi sumatif terdiri atas tes yang dirancang untuk domain yang terkait kriteria tertentu dan memberikan peluang umpan balik dari pengguna. Evaluasi yang akan dilakukan peneliti yaitu evaluasi respon siswa terhadap aplikasi dan evaluasi hasil pembelajaran siswa .

\section{HASIL}

Dalam pengembangannya CD interaktif AMT diujicobakan dalam proses pembelajaran sebagai media penunjang pembelajaran. Desain media CD interaktif AMT beserta materi yang telah dikembangkan divalidasi oleh pakar atau ahli sebelum diujicobakan untuk mengetahui kelayakannya. Validator terdiri atas ahli media pembelajaran, dan ahli materi serta kemudian direspon oleh siswa. Uji validasi dilakukan dengan 2 tahap, yakni tahap 1 sebagai tahap awal dan tahap 2 sebagai tahap akhir atau tahap perbaikan. Berdasarkan hasil penilaian oleh pakar atau ahli media dan ahli materi dilakukan perbaikan pada tampilan media serta materi yang dikembangkan.

CD interaktif AMT ini dikembangkan dengan tujuan agar pembelajaran siswa lebih aktif dan komunikatif, sehingga menghasilkan tingkat konsentrasi belajar dan pemahaman materi siswa dalam jangka panjang serta menciptakan pembelajaran yang efektif sesuai dengan karakteristik siswa. Produk yang dihasilkan dalam penelitian dan pengembangan ini 
berupa media CD interaktif AMT yang diharapkan layak digunakan dalam pembelajaran. Selanjutnya peneliti mengujicobakan produk di SDN Tandang 01 Semarang untuk mengetahui hasil penilaian respon siswa.

\section{Pengembangan CD interaktif AMT}

$C D$ interaktif $A M T$ ini dikembangkan dengan menghasilkan produk media pembelajaran. Kegiatan dalam pembelajaran berjalan sesuai dengan panduan media CD interaktif AMT. Dalam pengembangan $C D$ interaktif $A M T$ ini dikembangkan indikator pencapaian kompetensi berdasarkan masing-masing kompetensi dasar, hal ini ditujukan agar produk penelitian yang berupa media CD interaktif AMT ini mampu mencakup indikator pada masing-masing kompetensi dasar.

Sebagaimana Mas'ud (2014) dan Fakhrudin (2015), pada prosesnya diawali dengan analisis proses pembelajaran dan media yang bersifat visual dan terbatas dalam segi tampilan ukuran media maka dikembangkan menjadi CD interaktif AMT. Desain media CD interaktif AMT yang digunakan dalam penelitian ini dikembangkan dari media yang telah ada digunakan dalam pembelajaran, salah satunya konsep bilangan bulan dengan garis bilangan dan manik-manik bilangan (Suwarni, 2014).

Media CD interaktif AMT ini dikembangkan dengan menetapkan tujuan pengembangan, mengidentifikasi kompetensi inti dan kompetensi dasar, menyusun desain media CD interaktif AMT, dan mengembangkan media CD interaktif AMT. Media CD interaktif AMT dikembangkan dengan program Lectora Inspire yang divariasikan dengan penyertaan animasi, gambar, video, serta pemanfaatan musik yang berupa instrumen musik sehingga tercipta suatu media pembelajaran audio-visual yang komunikatif dan menarik bagi siswa.

Dalam pengembangannya $C D$ interaktif AMT diujicobakan dalam proses pembelajaran sebagai media penunjang pembelajaran. Desain media CD interaktif AMT beserta materi yang telah dikembangkan divalidasi oleh pakar atau ahli sebelum diujicobakan untuk mengetahui kelayakannya. Validator terdiri atas ahli media pembelajaran, dan ahli materi serta kemudian direspon oleh siswa. Uji validasi dilakukan dengan 2 tahap, yakni tahap 1 sebagai tahap awal dan tahap 2 sebagai tahap akhir atau tahap perbaikan. Berdasarkan hasil penilaian oleh pakar atau ahli media dan ahli materi dilakukan perbaikan pada tampilan media serta materi yang dikembangkan.

$C D$ interaktif $A M T$ ini dikembangkan dengan tujuan agar pembelajaran siswa lebih aktif, komunikatif sehingga menghasilkan tingkat konsentrasi belajar dan pemahaman materi siswa dalam jangka panjang serta menciptakan 
Sukamto \& Asry Kusuma Wardani, Pembelajaran Matematika Menggunakan CD Interaktif...

pembelajaran yang efektif sesuai dengan karakteristik siswa. Produk yang dihasilkan dalam penelitian dan pengembangan ini berupa media CD interaktif AMT yang diharapkan layak digunakan dalam pembelajaran. Selanjutnya peneliti mengujicobakan produk di SDN Tandang 01 Semarang untuk mengetahui hasil penilaian respon siswa.

\section{PEMBAHASAN}

Secara umum dalam penelitian dan pengembangan ini, peneliti menggunakan dasar metode pengembangan ADDIE. Metode ini terdiri dari lima tahap utama, yaitu (1) analysis, untuk menentukan potensi dan permasalahan serta kompetensi siswa, (2) design, menentukan kompetensi khusus, silabus, RPP, evaluasi, materi, serta media pembelajaran, (3) development, memproduksi media pembelajaran berupa CD interaktif AMT, (4) implementation, melaksanakan program pembelajaran dengan menerapkan desain atau spesifikasi program produk pembelajaran, (5) evaluation, melakukan evaluasi produk yang dikembangkan.

Pengembangan CD interaktif AMT ini diharapkan mampu menjadi suatu media pembelajaran yang dapat digunakan guru untuk menciptakan suasana pembelajaran yang aktif, komunikatif, efektif yang sesuai dengan karakteristik siswa. Sebagaimana pendapat Gerlach \& Ely (dalam Arsyad, 2013) serta Daryanto (2013), bahwa media bisa berupa apa saja, asalkan dipergunakan secara efektif, maka akan dapat meningkatkan hasil belajar siswa.

Adapun tahapan yang harus dilakukan untuk memperoleh suatu media $C D$ interaktif AMT yang valid dan sesuai dengan materi pembelajaran adalah melalui tahap validasi ahli media dan validasi ahli materi, serta direspon oleh siswa dengan menggunakan angket.

Ketika tahap validasi oleh ahli media dan ahli materi, peneliti menyerahkan media beserta materi yang dikembangkan kemudian validator menilai produk tersebut melalui angket yang disediakan oleh peneliti dengan menggunakan 2 tahap, yaitu tahap 1 sebagai awal validasi produk dan tahap 2 sebagai tahap akhir atau tahap perbaikan.

Berdasarkan penilaian pada tahap akhir yang dilakukan oleh ahli media didapat hasil persentase penilaian sebanyak $89,58 \%$ dengan kriteria sangat baik, sedangkan penilaian oleh ahli materi didapat hasil persentase sebanyak $90,42 \%$ dengan kriteria sangat baik, selanjutnya produk di ujicobakan pada siswa kelas IV SDN Tandang 01 Semarang untuk mengetahui tingkat persentase respon siswa mengenai hasil produk yang dikembangkan. Siswa mengisi angket penilaian setelah dilakukan ujicoba produk dan menganalisis hasil penilaian angket siswa. Berdasarkan data yang diperoleh, persentase hasil penilaian siswa 
terhadap CD interaktif AMT sebanyak $87,65 \%$ dengan kriteria sangat baik. Sikap positif yang ditunjukkan oleh siswa ini mengindikasikan bahwa penggunaan media dapat menumbuhkan minat belajar siswa (Daryanto, 2013).

Hasil belajar siswa setelah menggunakan $C D$ interaktif berbeda dengan sebelum menggunakan media. Pada rata-rata nilai 36 siswa kelas IV SDN Tandang 01 mengalami perbedaan yaitu nilai ratarata pada meningkat sebesar 59\%. Nilai yang diperoleh kemudian diolah untuk uji beda menggunakan paired samples t-test. Hasil perhitungan menggunakan rumus $\mathrm{t}_{\mathrm{o}}=\frac{\mathrm{M}_{\mathrm{D}}}{\mathrm{SE}_{\mathrm{MD}}}$ (Sudijono, 2009) menghasilkan $\mathrm{t}_{\mathrm{o}}$ $=9,056$ dan $t$ tabel $=2,030$, itu menunjukkan bahwa to $>$ tabel. Jadi, dapat ditarik kesimpulan bahwa $\mathrm{H}_{\circ}$ ditolak yang artinya terdapat perbedaan hasil belajar siswa sebelum dan sesudah diberi perlakuan. Peningkatan hasil belajar yang signifikan ini mendukung apa yang dikemukakan oleh Daryanto (2013), bahwa pemanfaatan media pembelajaran yang sesuai (seperti halnya $C D$ interaktif) dapat meningkatkan hasil belajar siswa.

Berdasarkan range persentase, kriteria kualitatif, dan perbedaan hasil belajar siswa, tampak bahwa media CD interaktif AMT yang disusun berdasarkan materi dan kompetensi yang ada ini sangat baik sehingga dapat dinyatakan bahwa CD interaktif AMT layak digunakan dalam pembelajaran matematika materi operasi hitung bilangan bulat pada siswa kelas IV SD yang menurut Karim (1996) merupakan materi yang tergolong sulit.

\section{SIMPULAN}

Simpulan yang dapat diambil pada penelitian pengembangan ini adalah sebagai berikut:

1. Pengembangan media $C D$ interaktif AMT dengan Lectora Inspire pada materi operasi hitung bilangan bulat adalah sebagai berikut: Setelah melewati tahapan analisis (analysis), perencanaan (design), pengembangan (development), implementasi (implementation), dan evaluasi (evaluation) media CD interaktif AMT ini layak digunakan sebagai acuan bagi guru dan siswa dalam kegiatan pembelajaran. Penilaian kelayakan CD interaktif AMT ini dilakukan oleh ahli media dan ahli materi diperoleh penilaian sangat baik (SB) dengan persentase keidealan $89,58 \%$ dan penilaian sangat baik (SB) dengan persentase 90,42\%. CD interaktif AMT diujicobakan ke siswa kelas IV SDN Tandang 01 Semarang dengan hasil persentase keidealan sebesar 93,05\%, sehingga dapat dikatakan bahwa media CD interaktif AMT ini layak digunakan dalam pembelajaran.

2. Hasil belajar siswa diketahui berdasarkan paired samples t-test, dengan to $=9,056$ dan tabel $=2,030$. Jadi to $>$ ttabel maka $\mathrm{H}_{\mathrm{o}}$ ditolak artinya ada perbedaan antara hasil belajar 
Sukamto \& Asry Kusuma Wardani, Pembelajaran Matematika Menggunakan CD Interaktif...

siswa sebelum dan sesudah diberi perlakuan. Dilihat dari nilai rata-rata hasil belajar siswa yaitu 45,83 pada pretest dan 72,92 pada posttest. Selisih rata-rata antara pretest dan posttest yaitu 27,09 atau sebesar $59 \%$. Dari selisih tersebut dapat dikatakan bahwa media CD interaktif AMT layak digunakan.

\section{REFERENSI}

Arsyad, A. (2013). Media pembelajaran. Jakarta: PT. Rajagrafindo Persada.

Daryanto. (2013). Media pembelajaran. Yogyakarta: Gava Media.

Fakhrudin, A. (2015). Pengembangan media fun learning berbasis multimedia interaktif dengan memanfaatkan Lectora untuk pembelajaran tematik terintergrasi kelas IV SD Bunayya Semarang. (Skripsi). Semarang: Universitas PGRI Semarang. Tidak dipublikasikan.

Karim, M. A. (1996). Pendidikan matematika 1. Malang: Depdikbud.

Mas'ud, M. (2014). Membuat multimedia pembelajaran dengan Lectora. Yogyakarta: Pustaka Shonif.

Pribadi, B. A. (2009). Model desain sistem pembelajaran. Jakarta: Dian Rakyat.

Setyosari, P. (2012). Metode penelitian pendidikan dan pengembangan, Jakarta: Kencana.

Soegeng, A. Y. (2006). Dasar-dasar penelitian: bidang sosial, psikologi, dan pendidikan. Semarang: IKIP PGRI Semarang Press.

Sudijono, A. (2009). Pengantar statistika pendidikan. Jakarta: Rajawali Press.

Sugiyono. (2010). Metode penelitian pendidikan pendekatan kuantitatif, kualitatif dan R\&D. Bandung: Alfabeta.

Sukmadinata, N. S. (2013). Metode penelitian pendidikan. Bandung: PT. Remaja Rosdakarya.

Suwarni. (2014). Meningkatkan hasil belajar siswa pokok bahasan penjumlahan dan pengurangan bilangan bulat dengan media manikmanik pada siswa kelas IV SDN Tanggul Wetan 02 tahun ajaran 2011/2012 Kec. Tanggul Jember. Pancaran Pendidikan [Online]. 3(3), pp. 177-186. Tersedia: http://jurnal.unej.ac.id/index.php/pan caran/article/viewFile/774/592/

Undang-Undang Republik Indonesia Nomor 20 Tahun 2003, Pasal 1 ayat 19, tentang Sistem Pendidikan Nasional. 